\title{
Recovery of equine oocytes by scraping of the follicular wall with different specifications of needles and morphological analysis of cumulus oophorus
}

\section{Recuperação de oócitos equinos por raspagem da parede folicular com diferentes especificações de agulhas e análise morfológica do cumulus oophorus}

\begin{abstract}
Suellen Miguez González'; Camila Bizarro da Silva²; Andressa Guidugli Lindquist ${ }^{3}$; Isabela Búfalo ${ }^{3}$; Fernanda Zandonadi Machado ${ }^{1}$; João Vitor Ravagnani Bueno ${ }^{3}$; Larissa Corrêa Scarpin ${ }^{3}$; Larissa Zamparone Bergamo ${ }^{1}$; Katia Cristina Silva-Santos ${ }^{4}$; Luciana Simões Rafagnin Marinho4; Marcelo Marcondes Seneda ${ }^{5 *}$
\end{abstract}

\begin{abstract}
In follicular aspiration, physical aspects are of high significance for the technique to succeed, such as vacuum pressure, caliber of the needle and the way the follicular wall curettage is performed. The aim of this study was to investigate the recovery rate of equine oocytes aspirated by scraping of the follicular wall, testing different calibers of disposable needles, as well as the morphological evaluation of the cumulus oophorus complexes (COCs). Mares ovaries $(n=447)$ obtained at a local slaughterhouse were transported to the laboratory in a thermal container $\left(20^{\circ} \mathrm{C}\right)$ and had the tunica albuginea and connective tissues dissected. The aspirated follicles had 10 to $25 \mathrm{~mm}$ in diameter, and 30x8 (21G 1 1/4) or 40x12 $\left(18 \mathrm{G} 1 \frac{1}{2}\right)$ needles were used for the aspiration, forming group $A(G-A)$ and group $B(G-B)$, respectively. In G-A and G-B, 480 and 548 follicles were aspirated, respectively. Under the stereomicroscope, the oocytes were evaluated according to the quality of the ooplasm and characteristics of the cumulus cells (grade I, II, III and denuded). The statistical analysis was performed using the Student's t-test, logistic regression and test of proportions, and differences were considered significant when $\mathrm{P}<0.05$. There was no difference between recovery rates of groups G-A $(66.5 \% ; 330 / 496)$ and G-B $(65.5 \% ; 359 / 548)$. In the G-A group, grade II oocytes were related to higher recovery rates $(46.9 \% ; 145 / 330)$ than grade I $(23.6 \% ; 72 / 330)$, grade III $(20.6 \% ; 59 / 330)$ and denuded oocytes $(8.5 \% ; 24 / 330 ; \mathrm{P}<0.05)$. However, in G-B, there was no statistical difference regarding the quality of the recovered oocytes: grade I $(23.4 \%$; $77 / 359)$, grade II $(43.2 \% ; 145 / 359)$, grade III $(22.5 \% ; 73 / 359)$ and denuded $(11.1 \% ; 32 / 359)$. The 30x8 $\left(21 \mathrm{G} 1 \frac{1}{4}\right)$ needle provided a higher proportion of grades I and II oocytes than the 40x12 (18G $\left.1 \frac{1 / 2}{2}\right)$ needle, with $72.4 \%(239 / 330)$ and $65 \%(233 / 359 ; \mathrm{P}<0.05)$, respectively. Both calibers of needles tested in this study provide efficient oocyte recovery rates. Aspiration with 30x8 (21G 1 1/4) needles resulted in a higher proportion of morphologically good equine oocytes for use in reproductive biotechnologies. Key words: Cumulus oophorus, horses, needle, oocytes, scraping the follicular wall
\end{abstract}

\footnotetext{
${ }^{1}$ Discentes do Curso de Mestrado do Programa de Pós-Graduação em Ciência Animal, Universidade Estadual de Londrina, UEL, Londrina, PR, Brasil. E-mail: suellenmgonzalez@gmail.com; ferzmachado@hotmail.com; larissabergamo1@hotmail.com

2 Discentes do Curso de Doutorado do Programa de Pós-Graduação em Ciência Animal, UEL, Londrina, PR, Brasil. E-mail: camilabizarros@gmail.com

${ }^{3}$ Discentes do Curso de Graduação em Medicina Veterinária, UEL, Londrina, PR, Brasil. E-mail: andressalindquist@gmail.com; isabela_bufalo@homail.com; joaovrbueno@gmail.com; larissa.scarpin@hotmail.com

${ }^{4}$ Pós-Dras ${ }^{-}$,UEL, Londrina, PR, Brasil. E-mail: katiasilva.vet@gmail.com; lucianaraf@gmail.com

${ }^{5}$ Prof., Dept ${ }^{\circ}$ de Clínicas Veterinárias, Laboratório de Reprodução Animal, Centro de Ciências Agrárias, UEL, Londrina, PR, Brasil. E-mail: mseneda@uel.br

* Author for correspondence
} 


\title{
Resumo
}

\begin{abstract}
Na obtenção de oócitos para a espécie equina, aspectos físicos são de alta significância para o sucesso da técnica, como a pressão de vácuo e o calibre de agulha utilizado, além da forma como é realizada a raspagem da parede folicular. O objetivo deste estudo foi investigar o índice de recuperação de oócitos equinos aspirados pela técnica de raspagem da parede folicular, testando calibres distintos de agulhas descartáveis, assim como avaliação morfológica dos complexos cumulus oophorus (CCOs). Foram utilizados ovários de éguas ( $\mathrm{n}=447)$, obtidos em abatedouro local, transportados ao laboratório em recipiente térmico $\left(20{ }^{\circ} \mathrm{C}\right)$ e submetidos à dissecação da túnica albugínea e tecidos conectores. Os folículos aspirados obtinham diâmetro entre $10 \mathrm{~mm}$ a $25 \mathrm{~mm}$, e para tanto utilizou-se a agulha 30x8 (21G $1 \frac{1}{4}$ ) ou 40x12 (18G 1 1/2), formando respectivamente, o grupo A (G-A) e grupo B (G-B). No G-A e G-B aspiraram-se 480 e 548 foliculos, respectivamente. Sob lupa estéreo-microscópica avaliou-se os oócitos quanto à qualidade do ooplasma e características das células do cumulus oophorus (grau I, II, III e desnudo). Para análise estatística utilizou-se teste t Student, regressão logistica e teste de proporções, e as diferenças foram consideradas significativas quando $\mathrm{P}<0,05$. A taxa de recuperação entre G-A e G-B não apresentou diferença; 66,5\% (330/496) e 65,5\% (359/548), respectivamente. Houve diferença quanto à qualidade dos oócitos no G-A, no qual os oócitos de grau II obtiveram melhor taxa $(46,9 \%$; $145 / 330 ; \mathrm{P}<0,05)$ frente ao grau I $(23,6 \% ; 72 / 330)$, grau III $(20,6 \% ; 59 / 330)$ e desnudo $(8,5 \% ; 24 / 330)$. Entretanto, no G-B não houve diferença estatística quanto aos graus de qualidade do CCOs recuperados, grau I (23,4\%; 77/359), grau II (43,2\%; 145/359), grau III $(22,5 \%$; 73/359) e desnudo $(11,1 \% ; 32 / 359)$. A agulha 30x8 (21G 1 1/4) porporcionou maior proporção de oócitos de grau I e II aspirados do que a agulha 40x12 (18G 1 11/2), com 72,4\% (239/330) e 65\% (233/359; $\mathrm{P}<0,05)$, respectivamente. Ambos os calibres de agulhas testados proporcionam taxas eficientes de recuperação de oócitos. A aspiração com agulha 30x8 (21G 1 1 1/4) apresentou maior proporção de oócitos equinos de melhor qualidade morfológica para aplicação em biotécnicas reprodutivas.
\end{abstract}

Palavras-chave: Agulha, cumulus oophorus, equinos, oócitos, raspagem da parede folicular

\section{Introduction}

In horse cloning by somatic nuclear transfer, oocytes derived from slaughterhouse ovaries are used as receptor cells. Such source of oocytes is explained by the large amount of gametic cells required to generate embryos and therefore produce successful pregnancies. In an attempt to obtain pregnancies after the transfer of equine clone embryos, 841 oocytes were used; which resulted in the implantation of 17 embryos, out of which only one developed to term (HALL et al., 2013). Therefore, recovery rates and oocyte quality can influence in vitro maturation rates, consequently affecting the achievement of better pregnancy outcomes (HINRICHS, 2005).

Animals slaughtered at abattoirs are an abundant and interesting source of gametes, even if the origin of the female donors, as well as oocyte quality, is unknown. As a result, these animals are considered excellent experimental models and sources of material for both training and application of different biotechnologies (OLIVEIRA et al., 2012).

The equine species has a low oocyte recovery rate when compared to other farm animals (SHABPAREH et al., 1993). In horses, cumulus oophorus complexes (COCs) are more strongly adhered to the follicular wall, directly influencing both in vivo and in vitro recovery rates (CURCIO et al., 2006). Consequently, it is important to perform movements of scraping or curettage of the follicular wall during follicle aspiration. These movements aim to disrupt the close connections between the cumulus cells and the granulosa membrane and between the granulosa membrane and the follicular wall, releasing the COCs (DELL'AQUILA et al., 2001). 
Techniques for oocyte recovery include ultrasound-guided follicular aspiration or OPU (Ovum Pick up), follicular wall curettage/scraping and ovary slicing, or even combinations of these techniques. During follicular aspiration by the scraping technique, physical aspects such as vacuum pressure, caliber of the needle and the way the follicular wall scraping is performed are of high importance for the success of the procedure (CURCIO et al., 2006; CREMONESI et al., 2010). Importantly, technicians need to be trained to obtain satisfactory outcomes.

The potential for oocyte maturation, fertilization and embryo development rates is estimated based on the characteristics of the COCs. The evaluation of these cells is performed subjectively under a stereomicroscope, in which the presence and/ or cumulus expansion is classified into different grades. This method also comprises a comparative character, especially regarding the bovine species, and the differences between both species are frequently not taken into consideration (OLIVEIRA et al., 2012).

Therefore, we proposed an investigation regarding: i) the recovery rate of oocytes aspirated by the follicular wall scraping technique; ii) different calibers of needles; iii) morphological evaluation of the COCs.

\section{Material and Methods}

\section{Ovary collection and transportation}

This study was performed with equine ovaries $(n=447)$ obtained from a slaughterhouse located close to the Laboratory of Animal Reproduction, collected from September to December of 2014 (latitude $23^{\circ} 17^{\prime} 34^{\prime \prime} \mathrm{S}$ and longitude $51^{\circ} 10^{\prime}$ 24 " W). The ovaries were transported to the laboratory at room temperature $\left(20{ }^{\circ} \mathrm{C}\right)$ in a thermal container.

\section{Ovarian processing}

The ovaries were held in beakers containing $0.9 \%$ saline solution in a water bath at $36{ }^{\circ} \mathrm{C}$. The ovaries were then submitted to dissection of the tunica albuginea and connective tissues with the help of scissors, tweezers and scalpel blades, to allow the visualization of antral follicles (Figures $1 \mathrm{~A}$ and $1 \mathrm{~B})$.

All the antral follicles were aspirated by the same person, who was previously trained to perform the scraping technique in equine ovaries. All the aspirated follicles had 10 to $25 \mathrm{~mm}$ in diameter, and the aspirated follicular fluid containing the COCs was placed in $60 \mathrm{ml}$ tubes containing $1 \mathrm{ml}$ of heparin solution, which were held in water bath at $36{ }^{\circ} \mathrm{C}$. The follicles were randomly aspirated and allocated into two groups: Group A (G-A), aspirated with 30x8 (21G 1 1/4) needles; and group B (G-B), aspirated with 40x12 (18G 1 1/2) needles (Figures $1 \mathrm{C}$ and 1D).

The needles were attached to $20 \mathrm{ml}$ syringes containing $2 \mathrm{ml}$ of heparin, to prevent clot formation. In G-A and G-B, 480 and 548 follicles were aspirated, respectively (Figure 2). The follicular fluid containing the COCs collected from both groups remained in the $60 \mathrm{ml}$ tubes for 5 minutes before the searching for the COCs was performed.

Each $60 \mathrm{ml}$ tube was repeatedly washed with $0.9 \%$ saline solution using an embryo filter, until the liquid had a translucent color. The solution containing the COCs was transferred to Petri dishes and the filter was washed with the aid of a needle attached to a syringe, in order to release the COCs that were adhered to the filter. 
Figure 1. A: Removal of the ovarian connective tissues for visualization of the antral follicles; B: Ovary after dissection of the connective tissue, with the presence of antral follicles; $\mathrm{C}$ : Aspiration of equine ovary with needle and syringe; D: 30x8 21G 1 1 1/4 needle (green) and 40x12 18G 1 1/2 needle (pink) used for scraping of the follicular wall; E: Stereomicroscope field with oocytes recovered after the follicular wall scraping aspiration technique; F: Grade I oocyte, according to the classification of the cumlus oophorus cells.
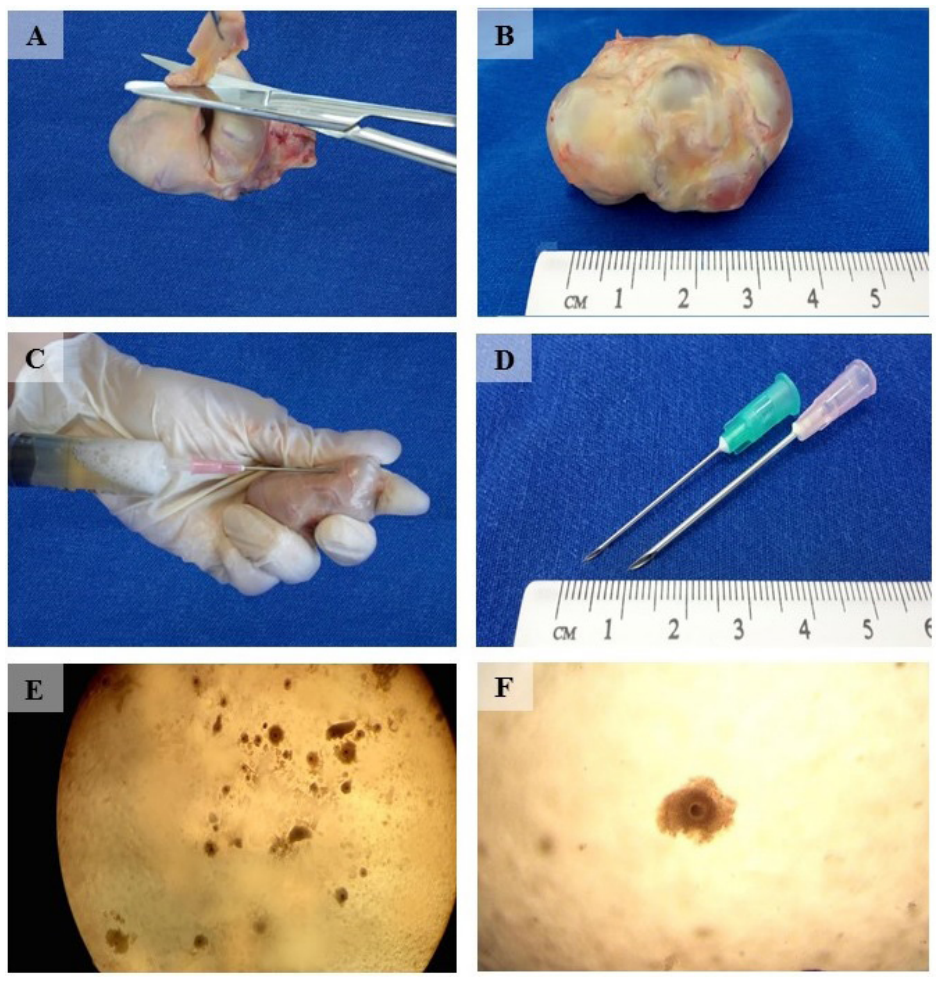

Figure 2. Experimental protocol describing equine oocyte recovery by the follicular wall scraping technique, with different specifications of needles and morphological analysis of the cumulus oophorus.

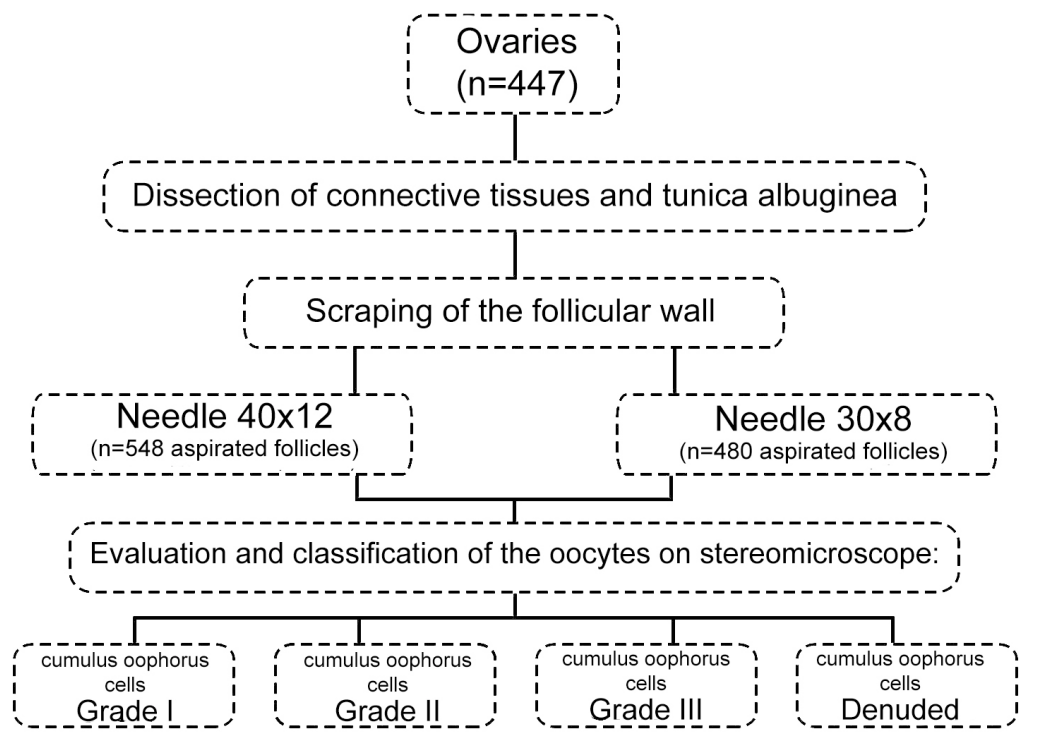


Under the stereomicroscope, the COCs were evaluated and classified according to characteristics of the cumulus cells and quality of the ooplasm. Cumulus cells were classified according to the integrity and characteristics of the ooplasm. Grade I COCs contained a compact cumulus with more than three layers of cells, spherical ooplasm with thin and homogeneous granulation, regularly filling the interior of the zona pellucida. Grade II COCs had a partially compact cumulus containing less than three layers of cells, spherical ooplasm with thin and homogeneous granulation, regularly filling the interior of the zona pellucida. Grade III COCs had a partial compact cumulus, with less than three layers of cells, ooplasm with heterogeneous granulation concentrated in the center of the oocyte or in the form of peripheral "spots". Degenerated COCs had a contracted ooplasm, creating a space between the cell membrane and the zona pellucida irregularly filling the perivitelline space; additionally, the cumulus cells may be expanded or absent and the ooplasm may be vacuolated or fragmented.

\section{Description of the follicular wall scraping technique}

Three trained teams were used for this study: the first team, composed by 4 people, was responsible for dissecting the ovaries; the second team, formed by only one person, performed the aspiration by follicular wall scraping; the third, composed by two persons, was responsible for classifying the CCOs. An average of 56 ovaries was aspirated per week, with a total of 447 ovaries distributed in eight weeks.

During follicle aspiration by the follicular wall scraping technique, a needle was attached to a $20 \mathrm{ml}$ syringe. With the bevel faced downwards, the needle was inserted into the portion between the ovarian parenchyma and the follicular wall. The follicle content was immediately aspired; concomitantly, the entire follicular wall was scraped through circular movements of the needle. The syringe plunger must be pressured at the same time that the circular movements are performed against the follicular wall. With this technique, follicle aspiration takes longer due to the need of scraping the follicular wall; also, equine follicles are larger in diameter and volume when compared to other farm animals.

All the three teams worked concomitantly, in order to optimize time. The average time for performing all the required procedures in each day of experiment was 3 to 4 hours.

\section{Statistical analysis}

The recovery rates were compared by a logistic regression test, data regarding oocyte quality were compared by the Student's t-test and the proportions of grade I and II oocytes was compared by a test of proportions. All analyzes were conducted by the Action 2.3 software (Campinas, São Paulo, Brazil) and differences were considered significant when $\mathrm{P}<0.05$.

\section{Results}

One thousand and twenty-eight follicles were aspirated from 447 ovaries by the follicular wall scraping technique. The total aspiration rate was 2.3 follicles/ovary (1028/477). The total oocyte recovery rate was 1.5 oocytes/ovary, and the average number of grade I and II oocytes per ovary was 0.85 (389/447).

In G-A, 480 follicles were aspirated and 330 oocytes were recovered; in G-B, 548 follicles were aspirated, resulting in 359 recovered oocytes. There was no difference between both needle calibers regarding oocyte recovery rates $(\mathrm{P}>0.05$; Table 1). However, differences concerning oocyte morphological quality of COCs were observed in G-A, in which grade II oocytes had higher recovery rates $(\mathrm{P}<0.05)$ than grade I, grade III and denuded oocytes (Table 2 ). 
Table 1. Number of aspirated follicles, recovered oocytes and oocyte recovery rate with the use of the follicular wall scraping technique, evaluating two different needle calibers.

\begin{tabular}{cccc}
\hline Needle caliber & $\begin{array}{c}\text { Number of aspirated } \\
\text { follicles }\end{array}$ & $\begin{array}{c}\text { Number of recovered } \\
\text { oocytes }\end{array}$ & Recovery rate \\
\hline G-A 30x8 (21G 1 1/4) & 496 & 330 & $66.5 \%^{\mathrm{a}}$ \\
G-B 40x12 (18G 1 1/2) & 548 & 359 & $65.5 \%^{\mathrm{a}}$ \\
\hline
\end{tabular}

Values with different letters in the same column differ significantly $(\mathrm{P}<0.05)$.

Table 2. Recovery rate of oocytes obtained by the follicular wall scraping technique, according to the cumulus oophorus complex (COC) classification.

\begin{tabular}{ccccc}
\hline \multirow{2}{*}{ Gauge needle } & \multicolumn{4}{c}{ COC classification } \\
\cline { 2 - 4 } & Grade I & Grade II & Grade III & Denuded \\
\hline G-A 30x8 (21G 1 1/4) & $23.6^{\mathrm{Ba}}$ & $46.9^{\mathrm{Aa}}$ & $20.6^{\mathrm{Ba}}$ & $8.5^{\mathrm{Ca}}$ \\
G-B 40x12 (18G 1 1/2) & $23.4^{\mathrm{ABa}}$ & $43.2^{\mathrm{Aa}}$ & $22.5^{\mathrm{Aa}}$ & $11.1^{\mathrm{Ba}}$ \\
\hline
\end{tabular}

Values with different capital letters in the same row differ significantly $(\mathrm{P}<0.05)$.

Values with different lowercase letters in the same column differ significantly $(\mathrm{P}<0.05)$.

A higher proportion of the sum of grade I and needles were used in comparison with 40x12 (18G grade II oocytes was observed when 30x8 (21G 1 1/4) 1 1/2) needles $(\mathrm{P}<0.05$; Table 3; Figures $1 \mathrm{E}$ and $1 \mathrm{~F})$.

Table 3. Proportion of grade I and II oocytes according to different needle calibers.

\begin{tabular}{cccc}
\hline \multirow{2}{*}{ Needle caliber } & \multicolumn{3}{c}{ COCs classification } \\
\cline { 2 - 4 } & Grade I & Grade II & Proportion of the sum of grades I and II (\%) \\
\hline G-A 30x8 (21G 1 1/4) & $72 / 330$ & $145 / 330$ & $72.4^{\mathrm{a}}$ \\
G-B 40x12 (18G 1 1/2) & $77 / 359$ & $145 / 359$ & $65.0^{\mathrm{b}}$ \\
\hline
\end{tabular}

Values with different letters in the same column differ significantly $(\mathrm{P}<0.05)$.

\section{Discussion}

In this study, 447 ovaries were subjected to follicle aspiration by the follicular wall scraping technique, resulting in an average of 2.3 follicles/ ovary (1028/477) and 1.5 recovered oocytes/ ovary. Accordingly, Erice et al. (1998) performed the same technique using $20 \mathrm{G}$ and $25 \mathrm{G}$ needles and 2 and $5 \mathrm{ml}$ syringes, obtaining an average of 1.8 oocytes/ovary. The sample amount used in this study to evaluate the follicular wall scraping technique was considered satisfactory, considering that other studies have reported similar numbers of ovaries (311 to 517 ovaries) (CURCIO et al., 2006; CREMONESI et al., 2010).

Cremonesi et al. (2010) compared the oocyte recovery rates obtained by follicular wall scraping and curettage and reported rates of $63 \%$ and $56 \%$, respectively. Our study resulted higher in rates, with $66.5 \%\left(30 \times 8\right.$ or $21 \mathrm{G} 1 \frac{1 / 4}{4}$ needles) and $65.5 \%$ (40x12 or $18 \mathrm{G} 1 \frac{1}{2}$ needles), demonstrating the possibility of a more effective application of this technique.

High oocyte recovery rates combined with the recovery of intact COCs were reported with the use of the follicular wall curettage technique, 
facilitating the classification of oocytes shortly after their recovery (HINRICHS et al., 1993; ALM et al., 1997). This was also evidenced in the present study with the use of the follicular wall scraping technique, in which the proportions of grade I and II recovered oocytes were $72.4 \%$ (30x8 or $21 \mathrm{G} 1 \frac{1 / 4}{4}$ needles) and 65\% (40x12 18G 1 1/2 needles).

Studies performed with bovine ovaries concluded that when aspiration was performed with larger caliber needles (18G), a higher amount of COCs were recovered; however, the oocytes presented lower quality (BOLS et al., 1996). The same study reported that when lower caliber needles were used $(21 \mathrm{G})$, fewer oocytes were recovered, but with higher quality. In the present study, a similar oocyte recovery rate was observed, but also a greater proportion of high quality oocytes with the smallest size needle $(21 \mathrm{G})$, evidenced by the higher rates of grade I and II oocytes. The superior results obtained with smaller caliber needles can be explained by the lower friction exerted in the passage of the oocyte through the needle. The "turbulence" suffered by the oocytes when aspirated by larger caliber needles can result in increased injury COCs (BOLS et al., 1996).

In the follicular wall curettage method, the isolation of each follicle is required, resulting in a laborious and time consuming technique (SHABPAREH et al., 1993). According to Cremonesi et al. (2010), the average time taken for scraping the follicular wall with the aid of a vacuum pump was of 4 to 5 hours. Our group estimated an average of 3 to 4 hours to accomplish each experimental day with the use of needles and syringes, resulting in a shorter time required.

Oocyte recovery by ovary aspiration is challenging in the equine species due to the high adhesion of the COCs to the follicular wall (DELL'AQUILA et al., 2001). Therefore, scraping of the follicular wall becomes necessary in both in vivo and in vitro methods in order to achieve greater efficiency of the technique and the recovery of better quality oocytes (ALM et al., 1997). Besides choosing the most appropriated technique, previous training of the team is essential to obtain higher numbers of recovered COCs.

The follicular wall scraping technique using needles and syringes represents an interesting method for obtaining oocytes to be used in cloning by nuclear transfer, considering that this biotechnique requires a substantial amount of oocytes (HALL et al., 2013). This method can be executed in a reasonable period of time and can be associated to the recovery of intact CCOs, providing promising maturation, blastocyst and pregnancy rates.

\section{Conclusion}

Both needle calibers tested provide efficient oocyte recovery rates. Aspiration with $30 \times 8$ (21G 1 $1 / 4$ ) needles provided a higher proportion of equine oocytes of high morphological quality for use in reproductive biotechnologies.

\section{References}

ALM, H.; TORNER, H.; KANITZ, W.; BECKER, F.; HINRICHS, K. Comparison of different methods for the recovery of horse oocytes. Equine Veterinary Journal Supplement, Malden, v. 29, n. 25, p. 47-50, 1997.

BOLS, P. E. J.; VAN SOOM, A.; YSEBAERT, M. T.; VANDENHEEDE, J. M. M.; KRUIF, A. Effects of aspiration vacuum and needle diameter on cumulus oocyte complex morphology and developmental capacity of bovine oocytes. Theriogenology, New York, v. 45, n. 5, p. 1001-1014, 1996.

CREMONESI, F.; ANDERSON, K.; LANGECONSIGLIO, A. Efficacy of tuohy needle in oocytes collection from excised mare ovaries. Veterinary Medicine International, New York, v. 2010, p. 1-4, 2010.

CURCIO, B. R.; FREY JÚNIOR, F.; BOFF, A. L. N.; LEON, P. M. M.; LINS, L. A.; ALBUQUERQUE, L. P.; RAMBO, G.; NOGUEIRA, C. E. W.; DESCHAMPS, J. C. Recuperação de oócitos equinos com Cumulus oophorus compacto por curetagem da parede folicular. Ciência Animal Brasileira, Goiânia, v. 7, n. 4, p. 417422, 2006. 
DELL'AQUILA, M. $\quad$ E.; MASTERSON, M.; MARITATO, F.; HINRICHS, K. Influence of oocyte collection technique on initial chromatin configuration, meiotic competence, and male pronucleus formation after ICSI of equine oocytes. Molecular Reproduction and Development, Malden, v. 60, n. 1, p. 79-88, 2001.

ERICE, I.; GIL, L.; JOSA, A.; ECHEGAMY, A.; MARTINEZ, F.; ESPINOSA, E. Effect of mare's age and recovery methods on the recovery rate of equine follicular oocytes for IVM procedures. Theriogenology, New York, v. 49, n. 4, p. 735-741, 1998.

HALL, V.; HINRICHS, K.; LAZZARI, G.; BETTS, D. H.; HYTTEL, P. Early embryonic development assisted reproductive technologies, and pluripotent stem cell biology in domestic mammals. The Veterinary Journal, London, v. 197, n. 2, p. 128-142, 2013.
HINRICHS, K. Update on equine ICSI and cloning. Theriogenology, New York, v. 64, n. 3, p. 535-541, 2005.

HINRICHS, K.; SCHIMIDT, A. L.; FRIEDMAN, P. P.; SELGRATH, J. P.; MARTIN, M. G. In vitro maturation of horse oocytes: characterization of chromatin configuration using fluorescence microscopy. Biology and Reproduction, Madison, v. 48, n. 2, p. 363-370, 1993.

OLIVEIRA, B. M. M.; GUIMARÃES, C. F.; BITTAR, J. N.; CELEGHINI, E. C. C.; FERNANDES, C. B. Transferência de oócitos em éguas. Veterinária $e$ Zootecnia, Botucatu, v. 19, n. 4, p. 460-469, 2012.

SHABPAREH, V.; SQUIRE, E. L.; SEIDEL, G. E. J. R.; JASKO, D. J. Methods for collecting and maturing equine oocytes in vitro. Theriogenology, New York, v. 40, n. 6, p. 1161-1175, 1993. 